\title{
殺線虫剤の殺菌力に関する二, 三の実験*
}

桂

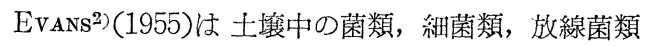
に及マ゙すフオルマリンと二硫化炭素の影響について, また ZENTMYER ${ }^{6}$ (1955) は一種の疫病菌に対するべ 一パムその他25種類の薬剤による抑制効果について, 夫々特殊のガラフ管を用的て実験を和てなつた。乙れ そ同様宗実験 は RUSHDI および JEFHERs4) (1956), 権藤および久保 ${ }^{3)}$ (1957), 高日, 角 および 上村 ${ }^{5}$ (1960)，荒木，豊田小よび鈴木1) (1961)などによつて おとなわれ，夫々特殊の装置によつて殺菌剂の土塨透 過と殺菌力につルて実験した。筆者は磨合せ連結する ととが出来る特殊のガラス管を用いて, 土壌に施用し た殺線虫凨のガス化による菌類への影響について実験 をおこなつたが，とこにその結果の二, 三について報 告するととにしたい.

なお本研究については本学研究員土倉竟一君かよび 武田薬品工業 大西常之君の本学在学中红助力学得た が，記して深謝の意を表する。

\section{実験および実験材料}

笔者第1図に示すような, 長さ $26 \mathrm{~cm}$, 径 $2 \mathrm{~cm}$ のガ ラス管 (A管) と, 長さ $27 \mathrm{~cm}$, 径 $2 \mathrm{~cm}$ のガラス管(B 管）とを試作した、A管は普通の試験管と同様に下端 を封じてあるが，上端はB管の下端と共に磨合せとな つており，密に連綕できるようにしまた B管は下端 が開放されており，A管と密に連結できる他に，上端

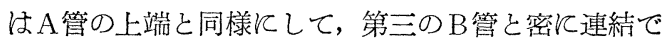
きるように用意した。したがつてB管を幾本も用意連 結して, ガラス管内の土裹を任意の潹さに装置すると とができる。

$\mathrm{A}$ 管の底に一定量の殺線虫剤を滴下し, 直ちにとと

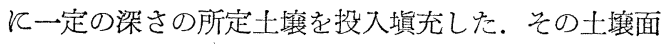
几濾紙を置き, 長さ $6 \mathrm{~cm}$, 径 $1 \mathrm{~cm}$ の軽く綿栓した管瓶 さ逆さに投入するが，乙の管瓶には斜面培地を用意し てあり，供試菌の菌叢径 $2 m m$ を白金耳で切取つて移 植してある. 実験の都合てょつてい管瓶の上飞憈紙を 插込み，その上飞所定の土镶学投入してB管底部の土
琦一

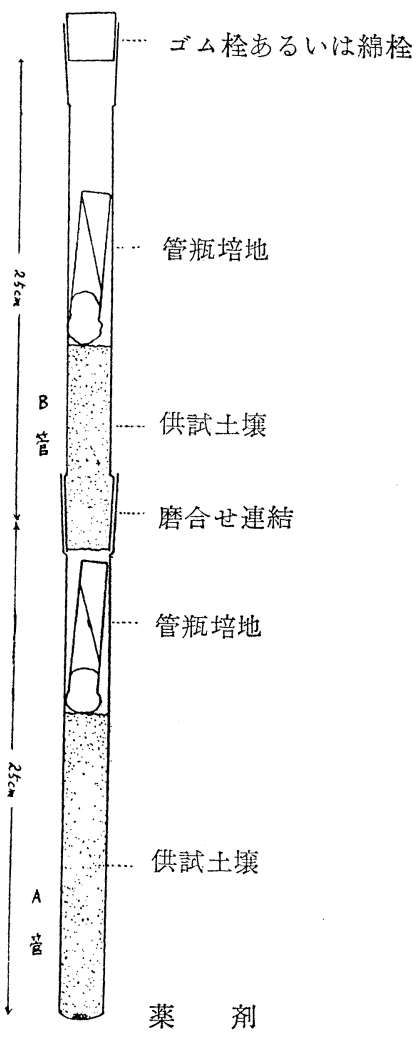

第1図 殺線虫剤の殺菌力に関する試験に供した 磨合せ連結がラス管

裹と相連続するとともできる。岕お管瓶の斜面培地は ジヤガイモ煎汁寒天を用的。

\section{実 験 結 果}

\section{1. スイカ蒙割病菌に対する実駼結果}

供試菌は当研究室保存のスイカ蔓割病菌 Fusarium oxysporum f. niveum で, 供試土壞はスイセンクキセ ンチュウ Ditylenchus dipsaci の発生激甚なタマネ ギ苗床の窝植滾土と ネコブセンチユウ Meloidogyne incognita acrita の発生激甚岕砂質壤土である. A管

*京都府立大学農学部植物病学研究室業績第62号 
の底に実際團場の $3.3 m^{2}$ 当り $52 m l$ おび $100 m l$ 亿相 当する概算量として，殺線虫片を夫々 $0.005 m l$ および $0.009 \mathrm{ml}$, 注射針で秤量滴下し, 固形のトリジパムは $0.008 \mathrm{~g}$ を科量して投入し，また乳剤およびベーパム は夫々水 $0.5 \mathrm{ml}$ 光加えて稀釈し, 值ちと土壤を填充し て深さ $15 \mathrm{~cm}$ とし，その上に濾紙を置き菌を移植した 管瓶培地を雨入した，B管の下端と濾紙を插込み，同 じ土袞を $20 \mathrm{~cm}$ 填充, その上亿濾紙を置き上記同様の 管瓶培地を投入し，B管の上端とゴム栓をした．管瓶 培地上の発育菌灇直径は 7 日後次, 生死判定注 12 日後 におこなつた。少菌の生死判定は, 管瓶培地学取出 して後におこる発育の有無と, 発育の不明瞭なものは 他のペトリ四の培地上飞供試菌叢片を移植して確実を 期した (第 1 表).

第1表の結果によると，スイカ瞢割病菌に対してべ 一パムは顕著な殺菌力を示し, 次いでトリジパムが優 れていた，NNR・13M乳剤40(日本曹達試製品）は土 壤の距離 $15 \mathrm{~cm}$ では殺菌力を示し注目されたが, 距離 $35 \mathrm{~cm}$ では発育抑制の効果は多られるが殺菌力は認め られなかつた。ネマーゴン乳剤40，ネマヒユーム油剤 30およびネマヒユーム乳剂48はレずれも土㙵 $15 \mathrm{~cm}$ を 透過して菌の発育抑制の効果を示すが，殺菌力はない ようである。ただしネマーゴン乳剤40 の一部に $15 \mathrm{~cm}$ 距離で発育が僅か、認められたの夕で, その後伸長し なかつたし，死滅したものとみられるものがあつた。 またてれらの結果からして殺線蝓のガスは土恠透過
によつて蕽度勾配を生じているととが推定出来ると思 丂.

\section{2. ビール麦根部の腐敗を原因する Pythium菌に 対する実験結果}

上記スイカ蔓割病菌と同様の方法で, 冬から早春に かけてビール麦の根部窝敗を原因するPythium菌 (本 菌に関する研究につ的ては近く発表の予定）に対する 殺線虫剈の殺菌力について実験を和てなつた。本実験 飞和ける殺線虫剤は実際圆場の $3.3 \mathrm{~m}^{2}$ 当り $52 \mathrm{ml}$ 相当 の概算量 $0.005 \mathrm{ml}$ を用いた. Pythium菌は発育が早い から, 菌丵発育直径の測定は 3 日後に, 菌の生死判定 は10日後におてなつた。また供試土畩はネコブセンチ ユウの発生の著しい畑の砂質壤土を用いた(第 2 表).

第 2 表の結果から，ビール麦の根部窝敗を原因する Pythium 菌に対して, ベーパムは顕著な殺菌力を示し 土壤の距離 $15 \mathrm{~cm}$ および $35 \mathrm{~cm}$ 共によく透過してすべて 菌が死減した。乙れに対してネマヒユーム乳剤48, ネ マーゴン乳剤 40 は $15 \mathrm{~cm}$ では殺菌力を示したが, $35 \mathrm{~cm}$ ではわずかと抑制効果が認められ，死滅するととはな かつた。 なおネマーゴン乳剤 $40035 \mathrm{~cm}$ 距離では，生 死判定の10日後に利て発育が不良であつたから，本 質的飞何らかの影響をらけているものと推察される。 ネマヒユーム油剂30はいずれの距離においても,わず かと発育の抑制を認めたのみで, 殺菌力は全く認めら れなかつた。てれらの結果からして殺線虫刘のガスは

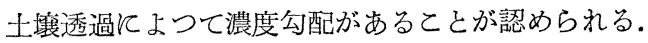

第1表 スイカ蔓割病菌に対する殺線虫刘の殺菌力検定結果（5装置平均）

\begin{tabular}{|c|c|c|c|c|c|c|c|c|c|c|c|c|}
\hline \multirow{3}{*}{$\frac{\text { 区別 }}{\text { 土壤の深さ }}$} & \multicolumn{3}{|c|}{ 菌叢発亩直径平均 } & \multirow{2}{*}{$(\mathrm{cm})$} & \multicolumn{2}{|c|}{ 菌の生 $(+)$} & \multirow{2}{*}{\multicolumn{2}{|c|}{$\begin{array}{c}\text { 死(一) 判定 } \\
B\end{array}$}} & \multirow{2}{*}{\multicolumn{2}{|c|}{$\begin{array}{c}\text { ホコブセン } \\
\text { チュウ検出数 } \\
\mathrm{A}\end{array}$}} & \multirow{2}{*}{\multicolumn{2}{|c|}{$\begin{array}{c}\text { スイセンクキセン } \\
\text { チュウ 検出 数 } \\
\text { B }\end{array}$}} \\
\hline & \multirow[b]{2}{*}{$15 \mathrm{~cm}$} & $\mathrm{~A}$ & B & & \multicolumn{2}{|r|}{ A } & & & & & & \\
\hline & & $35 \mathrm{~cm}$ & $\overbrace{15 \mathrm{~cm}}$ & $\frac{\mathrm{B}}{\mathrm{i} 35 \mathrm{~cm}}$ & $15 \mathrm{~cm}$ & $35 \mathrm{~cm}$ & $\longdiv { 1 5 \mathrm { cm } }$ & $35 \mathrm{~cm}$ & 範团 & 平均 & 範囲 & 平均 \\
\hline 無 処 理 & 4.2 & 4.2 & 4.6 & 4.5 & + & + & + & + & $7 \sim 37$ & 19.8 & $214 \sim 452$ & 330.8 \\
\hline ベ - パム & 0 & 0 & 0 & 0 & - & - & - & - & $0 \sim 13$ & 5.2 & $0 \sim 2$ & 0.6 \\
\hline $\begin{array}{l}\text { 亦マヒユーム } \\
\text { 油 㧩 } 30\end{array}$ & 0 & 2.0 & 0 & 2.2 & $t$ & + & + & + & $2 \sim 13$ & 7.2 & 0 & 0 \\
\hline 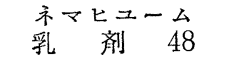 & & & 0 & 0.9 & & & + & + & & & $0 \sim 7$ & 2.0 \\
\hline 秀マー゙゙ン゙ & 0 & 2.8 & 0 & 1.4 & $\pm^{*}$ & + & + & + & $6 \sim 14$ & 9.4 & $0 \sim 19$ & 8.2 \\
\hline トリシパム & & & 0 & 0.9 & & & - & $\pm *$ & & & $0 \sim 11$ & 5.2 \\
\hline $\begin{array}{l}\mathrm{N} N \mathrm{R} \cdot 13 \mathrm{M} \\
\text { 乳 } \\
\text { 剂 }\end{array}$ & 0 & 2.0 & & & - & + & & & $4 \sim 38$ & 20.0 & & \\
\hline
\end{tabular}

註…A 区は薬剂 $0.009 \mathrm{ml}, \mathrm{B}$ 区は薬剂 $0.005 \mathrm{ml}$ 供試す. 温度…A 区は $21^{\circ} \sim 23.5^{\circ} \mathrm{C}, \mathrm{B}$ 区は $14.5^{\circ} \sim 20^{\circ} \mathrm{C}$. *........ 部に僅か発育が認められる。 線虫検出数…土塎 $30 \mathrm{~g}$ よりぶールマン氏法により検出す。なお土壤は下底より $18 \sim 30 \mathrm{~cm}$ 間を採取す。

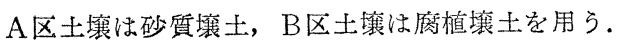


第 2 表 ビール麦根部腐敗を原因するPythium 菌に対する殺線虫剤の殺菌力検定結果（5装置平均）

\begin{tabular}{|c|c|c|c|c|c|c|}
\hline 調查事項 & 菌襒発育 & 圣平均 $(\mathrm{cm})$ & 菌の生 $(+$ & (-) 判定 & ネコブセン & 二ウ検出数 \\
\hline $\begin{array}{c}\text { 供試 土理の深さ } \\
\text { 桼郕 }\end{array}$ & $15 \mathrm{~cm}$ & $35 \mathrm{~cm}$ & $15 \mathrm{~cm}$ & $35 \mathrm{~cm}$ & 範国 & 平均 \\
\hline 無 処 理 & 7.5 & 6.5 & + & + & $99 \sim 27$ & 145.8 \\
\hline ベーパム & 0 & 0 & - & - & 0 & 0 \\
\hline $\begin{array}{l}\text { ネマヒューム } \\
\text { 油剂 } 30\end{array}$ & 1.1 & 2.2 & + & + & 0 & 0 \\
\hline 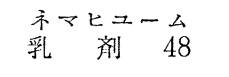 & 0 & 4.9 & - & + & $0 \sim 2$ & 0.8 \\
\hline 孚マー゙゙ン & 0 & 5.0 & - & $+*$ & $0 \sim 21$ & 10.8 \\
\hline
\end{tabular}

註 $\cdots$ 温度は $28^{\circ} \mathrm{C}$. 薬剤は $0.005 \mathrm{ml}$ を供試。その他は第 1 表の註に準ずる。

第 3 表 ナス半枯病菌に対する殺線虫䨩の殺菌力検定結果（5装置平均）

\begin{tabular}{|c|c|c|c|c|c|c|}
\hline$\widetilde{\text { 調查事項 }}$ & \multicolumn{2}{|c|}{ 菌叢発育直径平均 $(\mathrm{cm})$} & \multicolumn{2}{|c|}{ 菌の生 $(+)$ 死 $(-)$ 判定 } & \multicolumn{2}{|c|}{ センチュウ検出総数 } \\
\hline 土壌の深さ & $15 \mathrm{~cm}$ & $\overline{35} \mathrm{~cm}$ & $15 \mathrm{~cm}$ & $35 \mathrm{~cm}$ & $0 \sim 10 \mathrm{~cm}$ 間 & $20 \sim 30 \mathrm{~cm}$ 間 \\
\hline 理 & 3.3 & 3.4 & + & + & 226 & 201 \\
\hline ベーパ ム $\left\{\begin{array}{l}0.024 \mathrm{ml} \text { 区 } \\
0.012 \mathrm{ml} \text { 区 }\end{array}\right.$ & $\begin{array}{l}0 \\
0\end{array}$ & $\begin{array}{l}0 \\
0\end{array}$ & $\begin{array}{l}- \\
-\end{array}$ & $\overline{t^{*}}$ & $\begin{array}{l}0 \\
0\end{array}$ & $\begin{array}{l}0 \\
0\end{array}$ \\
\hline $\begin{array}{l}\text { 衤マヒユーム } 10.014 \mathrm{ml} \text { 区 } \\
\text { 油剤 } 30\{0.007 \mathrm{ml} \text { 区 }\end{array}$ & $\begin{array}{l}1.7 \\
2.2\end{array}$ & $\begin{array}{l}2.9 \\
3.0\end{array}$ & + & + & $\begin{array}{l}1 \\
2\end{array}$ & $\begin{array}{r}8 \\
10\end{array}$ \\
\hline
\end{tabular}

註N.*印は 5 装置中 4 装置に菌の生存がみられた。

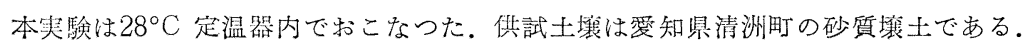

\section{3. ナス半枯病菌に対する実験結果}

上記スイカ蔓割病菌などの場合と同様の方法で, 愛 知県園芸試験場の石上孔一氏から分讓されたナス半枯 病菌 Fusarium oxysporum f. melongenaer対す当殺 菌力について実験学和てなつた。供試薬剤は実際固場 の3. $3 m^{2}$ 当りネマヒユーム油率30は $75 m l$ および 150 $m l$, 同じくベーパムは $100 \mathrm{ml}$ および $200 \mathrm{ml}$ 亿該当する 概算量として, 夫々前者は $0.007 \mathrm{ml}$ および $0.014 \mathrm{ml}$, 後者注 $0.012 \mathrm{ml}$ および $0.024 m l$ を用ら，A管の下底に 注射器で科量滴下した．なおべーパムは水 $1 m l$ を加光 て稀釈した。また菌丵発育直径の測定は 4 日後に，生 死判定は10日後におこなつた（第 3 表）。

第 3 表の結果によると,ベーパムは $0.012 m l$ 供試区 では土壤 $15 \mathrm{~cm}$ 距離を透過して顕著な殺菌力を示した が, $35 \mathrm{~cm}$ 距離では菌系の発育を全く抑制したが, 殺菌 効果媺弱のようで, 一部にかすか発育が認められ たのみであつた。乙れ亿対してべーパムの $0.024 \mathrm{ml}$ 供

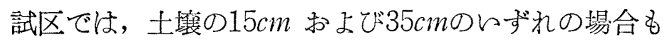
透過して殺菌力が認められた. しかしネマヒユーム油 羭30は, らずれの場合も菌系の発育に抑制的効果がみ られたが, 殺菌力はまつたく認められなかつた。なお

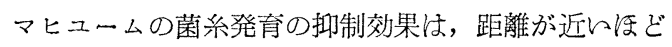

著しかつたが，土堙透過によつてガス濃度の勾配があ るよらである。

\section{論}

以上の実験結果から, 殺線虫剤のうちベーパムはス イカ蔓割病菌, ビール麦根部腐敂を原因するPythium 菌およびナス半枯病菌等の土壌病菌に対して顕著学殺 菌力を示すととが認められる。乙かしその殺菌力は 3 種の菌のらち Pythium 菌に対してか帘り敏感にはた らくようである。ナス半枯病菌住対しては 1 装置当り $0.012 m l$, つまり実際團場の $3.3 m^{2}$ 当り $100 m l$ 量とお レて, 薬剤との距離が $15 \mathrm{~cm}$ であると, 顕著岕殺菌力 があるが， $35 \mathrm{~cm}$ では 5 装置中 1 装置のみにおいて殺 菌効果が認められただけであり,ナス半枯病菌は他の 2 種菌に比べて, ベーパムに刘する抵抗性が多少大き ロもののようである。 またナフ半枯病菌に対する実験 結果から，ベーパムはそのガスが土㙵中を拡散する場 合 $\mathrm{K} 15 \mathrm{~cm}$ 距離と $35 \mathrm{~cm}$ 距離との間に, 濃度勾配がある ことを認めてよらのであろう。もちろん土壤中を透過 する場合のガフの濃度勾配は, ネマーゴン乳剤 40 , ト リジパム，NNR・13M乳剤40などでも認められた。

なおトリジパム, NNR・13M 乳凨40 は久イカ蔓割 
病菌に対して, 土壤中の距離 $15 \mathrm{~cm}$ 範团ならば殺菌力 が認められ，ネマーゴン乳剂40るね洞様とみて差支 えないが，ネマヒュームは殺菌力を有さないもののよ うである。ネマヒュームについてはナス半枯病菌に対

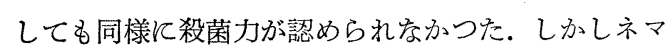
ヒユームはビール麦の根を侵すPythium 菌の一種に 対して, 土壤の距離 $15 \mathrm{~cm}$ 亿和いてのみ殺菌力示し たが，35cm では殆んど影響が認められないようであ つた.

以上のととから，ベーパムは殺線虫力および殺菌力 を共有する薬剤であり，トリジパムもとれに次ぐも のとみられる。またネマーゴンは土壇中の近距離に ある菌類に対して,多少の殺菌力がみられるけれども， ネマヒユームの殺菌力は殆んど期待出来ないようであ る.しかし病菌の種類によつて, それら殺線虫郕の殺 菌力は必ずしも同じでないととは, 実駼結果からみて 推定出来るようである。宗和筆者の考察した磨合せ連 結式のガラス管は, 種々の殺線虫剤の土燷中に利ける ガス蕽度勾配や殺菌力を比較検定するとつ的は, 充 分利用出来るもののように思われる。

\section{摘 要}

1. 本報告は筆者が考察した連結式ガラ久管によつ て, 殺線虫剤の土墥透過と殺菌力につけておてなつた 実験結果を述べた。

2. スイカ蔓割病菌に対してベーパムは土铱中の距 離 $15 \mathrm{~cm}, 35 \mathrm{~cm}$ レずれをも透過して後も顕著な殺菌力 を示し、トリジパムはそれに次ぎ，またネマーゴン乳

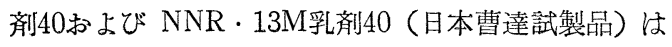

$15 \mathrm{~cm}$ 距離で殺菌力を示したが $35 \mathrm{~cm}$ 距離では抑制的効 果を示しただけであつた。

2. ビール麦根部の䆚敗を原因するPythium菌に対 しては, ベーパムは土壤 $15 \mathrm{~cm}, 35 \mathrm{~cm}$ 共に透過して殺 菌力を示したが，ネマーゴン乳鼡40，ネマヒユーム乳 剤48は $15 \mathrm{~cm}$ 距離のみで殺菌力が認められた.しかし ネマヒニーム油剤30では殺菌力が認められなかつた。

3. ナス半枯病菌に対しては, ベーパムが殺菌力を 示し，ネマヒューム油剤30はとれを認めなかつた。

4. 本実験のガラス管装置で, 土壤中を透過する殺 線虫郕のガス瀑度勾配を培養菌に対する抑制効果や殺 菌効果で恰定するととが出来るようであり，また殺線 虫剤の殺菌力は菌の種類によつて差があるように思わ れる。

\section{引用交献}

1. 荒木隆男・䅱田 栄・鈴木直治 (1961)：土之微 生物, $2,4-8$.

2. Evans, E. (1955) : Trans. Brit. mycol. Soc., 38, 335-346.

3. 権滕道夫 -久保利宏 (1957) : 鹿児島大農学報, 6, 101-107.

4. Rushdi, M. \& W. F. Jeffers (1956) : Phytopath., 46, 88-90.

5. 高日幸義-角 博次 ·上村昭二 (1960) : 高峰研 年報, 12, 295-299.

6. Zentmyer, G. A. (1955): Phytopath., 45, 398 -404 . 